\title{
EDITORIAL
}

\section{Lugares do corpo}

Com o presente título, a Revista Jangada teve como objetivo acolher trabalhos que discutissem questões relevantes sobre identidade e pertencimento, amparando-se em teorias ligadas aos estudos do espaço, diáspora e gênero. Esses conceitos estão em evidência em nossos dias. A 'identidade', como destacou Zygmunt Bauman (2005, p. 22), é o 'papo do momento', e a explicação para isso tem a ver com a atenção que dispensamos às coisas que desvanecem, fracassam, começam a se comportar estranhamente ou nos decepcionam de alguma forma.

No final do século XX, como escreveu Stuart Hall (2005, p. 9), um tipo diferente de mudança estrutural transforma as sociedades modernas, fragmentando as "paisagens culturais de classe, gênero, sexualidade, etnia, raça e nacionalidade, que, no passado, nos tinham fornecido sólidas localizações como indivíduos sociais". Hall discute aspectos relacionados às nossas noções de identidades culturais, observando tratar-se daqueles aspectos "que surgem de nosso 'pertencimento' a culturas étnicas, raciais, linguísticas, religiosas e, acima de tudo, nacionais" (p. 8). A expressão que nomeia o presente dossiê, "Lugares do corpo", no entanto, pode e deve remeter-nos também às noções de sexualidade e suas representações, bem como às questões que envolvem medidas coercitivas de controle e vigilância dos corpos, permitindonos pensar no conceito de "Espaço disciplinar" que, como destacou Michel Foucault (1987, p. 123 ), "tende a se dividir em tantas parcelas quando corpos ou elementos há a repartir", envolvendo procedimentos que resultam em conhecer, dominar, utilizar os indivíduos.

Os trabalhos acolhidos contemplam um horizonte de expectativas no campo da representação em que se cruzam essas e outras questões de modo a acrescentar novas inquietações para as pesquisa atuais. Os três primeiros trabalhos relacionam-se entre si mais de perto por apresentarem discussões sobre corpo e identidade. São eles: 1. "As geografias do exílio: lugares do corpo e da memória no conto de Mario Benedetti”, analisa o conto "Geografias", do escritor uruguaio Mario Benedetti, a partir da discussão sobre as marcas do exílio deixadas no sujeito; 2. "Travestilidade como denúncia política: performatividade de 


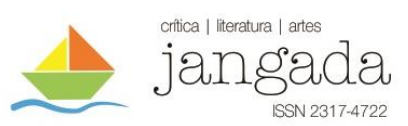

gênero e pananlillanismo em Sirena Selena vestida de Pena (2000)", analisa o romance da escritora porto-riquenha Mayra Santos-Febres e discute aspectos políticos presentes no tema da travestilidade; 3. "Como desaparecer sendo todas as coisas: derivação e polimorfia em Francesca Woodman”, aborda questões relacionadas às noções de dispersão, metamorfose e construção identitária na obra da fotógrafa norte-americana Francesca Woodman. O trabalhos subsequentes aproximam-se entre si por acrescentarem ao debate aqui proposto o interesse pela escrita de mulheres: 4. "O corpo feminino e os lugares de Seul: espaço, gênero e identidade no romance coreano The mother's Stake (Eommanui Malttuk), de Park Wan Seo", analisa os trânsitos imagéticos no/pelo espaço e discute o papel desempenhado pela literatura de autoria feminina no âmbito literatura contemporâneo da Coreia do Sul; 5. "Gênero e escrita feminina: uma abordagem literária sobre infâncias", analisa a infância no contexto brasileiro e argentino entre 1930 a 1940 a partir de autobiografias femininas; 6. "Espantosa Graça: a inquietude do eu em Paixão, de Alice Munro", analisa como a autora canadense Alice Munro desafia em sua narrativa pressupostos ligados a padrões tradicionais presentes na construção do feminino e do masculino. 7. "Alteridade e a identidade Rizoma”, revê conceitos de cultura e identidade sob ponto de vista bastante amplo, quiçá planetário, como sustenta o autor, no intuito de mostrar como a dispersão rizomática valoriza a diversidade; 8. "Borders: displacement and the constitution of subjectivity in Alias Grace (1996) by Margaret Atwood", à luz da crítica espacial e da teoria do gênero, analisa o romance da escritora canadense Margaret Atwood com a finalidade de desconstruir essencialismos sobre o sujeito-mulher. O bloco de artigos é concluído com o ensaio "A alteridade e a identidade rizoma", que propõe discutir a seguinte questão: como reconhecer e valorizar a teia rizomática de relações sem desvalorizar o individual?

Na sequência, publicamos a tradução realizada por Dirceu Magri” do artigo "La notion de transfert culturel”, de Michel Espagne, coroando o tema aqui proposto, pois as ideias e os grupos sociais, como observou Espagne, são suscetíveis “de passar de um espaço nacional ou linguístico, étnico ou religioso a outro" como "vetores de transferência cultural". Na seção "Poesia e Prosa", publicamos os poemas "Ânsia de ti" e "Galáxia Stelar", de Laura Assis, e "O fim é o remédio", de Danielle Melchiades. Com a diversidade de autores dialogando em torno do tema "lugares do corpo", desejamos a todos que buscarem esse dossiê excelentes leituras.

\section{BIBLIOGRAFIA:}

BAUMAMAN, Zygmunt. Identidade - entrevista a Benedetto Vecchi. Trad. Carlos Alberto Medeiros. Rio de Janeiro: Jorde Zahar Ed., 2005. 
FOUCAULT, Michel. Vigiar e punir: nascimento da prisão. Trad. Raquel Ramalhete. Petrópolis: Vozes, 1987.

HALL, Stuart. A identidade cultural na pós-modernidade. Trad. Tomaz Tadeu da Silva, Guaracira Lopes Louro. 10 ed. Rio de Janeiro: DP\&A, 2005.

\author{
Dirceu Magri \\ Joelma Santana Siqueira \\ Editores
}

